\title{
A SEARCH FOR THE MEANING OF LIFE: JAMES A. MICHENER, YOUTH, AND ETERNAL SPAIN
}

\author{
Mark DeStephano \\ Saint Peter's University, Jersey City (New Jersey, USA)
}

\begin{abstract}
This article will examine James A. Michener's Iberia as one of the finest books written during the twentieth century on Spain. During a period of over forty years, Michener made numerous trips to Spain, calling it his «second home», and, through travels to virtually every corner of the nation, aided by thousands of conversations with Spaniards from prominent to poor, Michener pieced together a fascinating collage of Spain and its people. His exhaustive research and reading, brought to bear on every page of Iberia, enabled Michener to write what is very possibly the most definitive one-volume chronicle of every aspect of Spanish civilization, from history, culture, food, music, art, philosophy, and literature, to bullfighting, festivals, politics, language, and pundonor. Finally, Iberia is a testimony to a lifelong love affair of an American who once went to Spain but whose spirit never left it, especially in the moment of his greatest personal crisis.
\end{abstract}

Keywords: James A. Michener, Iberia, Spain, Teruel, travel, Hispanophile.

\author{
UNA BÚSQUEDA DEL SENTIDO DE LA VIDA: \\ JAMES A. MICHENER, LA JUVENTUD Y LA ESPAÑA ETERNA
}

\section{RESUMEN}

Este artículo examina la obra Iberia de James A. Michener como uno de los mejores libros escritos durante el siglo xx acerca de España. Durante un período de más de cuarenta años Michener hizo muchas visitas a España, llamándola «mi segundo hogar», y, a través de sus viajes a casi cada rincón del país, ayudado por miles de conversaciones que había mantenido con españoles de los más prominentes a los más pobres, Michener tejió un tapiz extraordinario de España y su gente. Sus investigaciones y sus lecturas exhaustivas, que aparecen en cada página de Iberia, le facilitaron a Michener escribir la que posiblemente sea la mejor crónica en un volumen de cada aspecto de la civilización española, desde su historia, cultura, comida, música, arte, filosofía y literatura a la tauromaquia, los festivales, la política, la lengua e incluso el pundonor. Por último, Iberia es el testimonio del amor de toda la vida de un americano que una vez fue a Espańa, pero cuya alma nunca la dejó, sobre todo en el momento de la crisis más grande de su vida.

Palabras clave: James A. Michener, Iberia, España, Teruel, viaje, hispanófilo.

DOI: http://doi.org/10.25145/j.refiull.2019.38.003

Revista de Filología, 38; enero 2019, pp. 43-60; ISSN: e-2530-8548 
On Christmas morning of 1970 I was mesmerized by what I remember as being my favorite gift -the very first thing I took a picture of with my equally new «Instamatic» cube camera. It was a paperback copy of James A. Michener's Iberia: Spanish Travels and Reflections (1968), the passport for an extended and engrossing adventure for a twelve-year-old boy who had just completed his first year of Spanish study. My parents laughingly told me of how I used to speak Spanish phrases in my sleep, so intense were my encounters with the Spanish language, and so began a journey with Hispanic cultures that has lasted to this day, as I am moving well into the middle years of my career as a Professor of Spanish and Hispanic Studies. I could not put Michener's book down; moving from chapter to chapter was like taking a tour through Spain, but not just the Spain of tourist attractions. Michener's words and descriptions, I felt, were bringing me into the very heart of Spain, that ancient and glorious land that in countless ways was to change the history of the world.

Iberia was not the work of a neophyte. By the time of the work's publication in 1968, Michener (1907-1997) had already written eight novels and dozens of newspaper articles, had been awarded the 1948 Pulitzer Prize for his Tales of the South Pacific (1947), which was later adapted into the hit Broadway musical South Pacific, and had published seven non-fiction books. His early works, especially those he wrote before Iberia, reflect many of Michener's personal experiences as a naval officer in the South Pacific who had been assigned to work as a Navy historian. This was a task for which he was well prepared, having earned a bachelor's degree in English and History at Swarthmore College in Pennsylvania (Becker 1983: 4). Michener's works were noted for their mix of clear prose, exotic settings, exhaustive historical detail, and engrossing plots that were embedded into the histories of the places about which he wrote. The first of his historical novels, Hawaii (1959), reflected what was to become the hallmark of Michener's novels: deep research into the history, customs, folklore, and celebrated personages of the area or event in which his novels were set. Horace Sutton of the Saturday Review captured the attitude of many critics with regard to Michener's approach to writing Hawaii: «A masterful job of research, an absorbing performance of storytelling, and a monumental account of the islands from geologic building to sociological emergence as the newest and perhaps most interesting of the United States» (quoted in Day 1977: 102). Within nine weeks, Hawaii was at the top of the best-seller list, and Michener had settled upon the literary style that was to be his gateway to a faithful readership. The adaptation of several parts of the novel into film in 1966 and 1970 helped him to further popularize his work.

Not all critics, though, were enthusiastic about Michener's work. One example of an alternate evaluation of Hawaii was that of William Hogan of the Chicago Sunday Tribune, who voiced criticism that the writer would hear through much of his career as a novelist. Michener's characters, according to this critic, are "prototypes rather than people», and he often «sacrifices drama for pageantry, true characterization for literary showmanship" (quoted in Day 1977: 102). Such was the irony of Michener's career as a fiction writer. Generally garnering lukewarm praise from critics, he was wildly popular with everyday readers in the «Book of the Month Club» and with patrons of grocery-store reading racks. So successful was 
he, that it has been estimated that to date between 75 and 100 million copies of Michener's books, translated into thirty-two languages, have been sold the world over (The Economist 1997: 92).

When Michener passed away, the notion that he was a «popular» writer was so deeply ingrained that an obituary piece in the Spanish newspaper La Vanguardia remembered him as a "veterano del best-seller» [«veteran of the best-seller lists»] (Martín 1997: 51). However, this distinction did not always save him from caustic criticism. In his late years, for instance, the celebrated novelist Paul Theroux railed against him in the travel book The Happy Isles of Oceania (1992). Theroux considered that Michener's Return to Paradise, written decades earlier, not only had apparently maligned the Indians in Fiji, but was in general «superficial and dated and rather poorly written» (225). In short, he firmly dismissed Michener's characterization and berated his work for perpetuating myths, simplifying local cultures, and creating unreal portraits of lands and peoples:

These judgements (of Michener) are too silly to discuss. Michener is just another in the long parade of explorers and travelers and tourists who felt a need to invent the Pacific and to make it a paradise. How misleading it all is. The very name of the Pacific is a misnomer. But I should say that the very fact that so much written about the Pacific is inaccurate -indeed, most of it is utter crap-intensifies the pleasure of traveling there and gives it so much unexpectedness (Theroux 1992: 226).

However, as I will demonstrate later, unlike many of Michener's historical sagas, the travelogue Iberia: Spanish Travels and Reflections would be no figment of Michener's imagination. Quite to the contrary, it was to be solidly grounded on fact yet occasionally enveloped with a mist of epic and sobriety. Juan Cavestany, in the obituary that he wrote for the Spanish newspaper El Pais, points out that even though Michener may not have been a sophisticated craftsman with a gift for creating dialogues and portraits, he did excel instead as «un albañil de la narración geográfica-histórica con matices épicos» [«a builder of geographical-historical narratives with epic touches»] (1997: 44). This is what his fact-laden book of Spanish travels accomplishes.

Hailed by a number of critics as one of the most comprehensive travel books on Spain written during the twentieth century, Iberia is a tale told from the point of view of a bona fide Hispanophile. The Wall Street Journal acclaimed the book as «[m]assive, beautiful [...] unquestionably some of the best writing on Spain and the best that Mr. Michener has ever done on any subject», whilst the Saturday Review hailed Iberia as «[a] dazzling panorama [...] one of the richest and most satisfying books about Spain in living memory» (quoted in Michener 2015: i). Very early in the book, Michener declares his fascination and love for the conundrums that confront the traveler in Spain:

I knew that Spain was a special land, and I have spent many subsequent trips endeavoring to unravel its peculiarities. I have not succeeded, and in this failure I am not unhappy, for Spain is a mystery and I am not at all convinced that those who live within the peninsula and were born there understand it much better than 
I, but that we all love the wild, contradictory, passionately beautiful land there can be no doubt (1968: 25).

Iberia is a personal account that spans over forty years of Michener's experience with the language, people, history, and culture of Spain. Typical of the critical acclaim showered on the book is the assessment of Roberto Fuertes Manjón:

Iberia revela aspectos inéditos de la nación a través de la confluencia de diversas perspectivas. Curas, campesinos, poetas, alcaldes, toreros o nobles desfilan por sus páginas para ofrecernos con sus personales enfoques de la realidad de una imagen humana, comprensiva y totalizadora del país, con sus indudables miserias y grandezas, lo que complementa la visión intelectualizada de la realidad por parte del autor, mediatizada, a la vez, por la gran admiración que sintió por España (39). [Iberia reveals unknown aspects of the nation through the confluence of diverse perspectives. Priests, country folk, poets, mayors, bullfighters, or nobles parade across its pages to offer us, with their personal perspectives on reality, a human, sympathetic, and comprehensive portrayal of the country, with its undeniable miseries and grandeurs, which complements the author's intellectualized vision, mediated at the same time by the great admiration he felt for Spain].

A similar praise, voiced in the Houston Post, noted that «Michener writes with a delightful sense of continuing discovery and curiosity, and a sustaining affection for his subject» (quoted in Michener 2015: i). These positive appraisals saluted the author's book as a welcomed addition to American travel writing on Spain, deeming it worthy of the same recognition granted to other contemporary travel texts.

The title Iberia reveals Michener's understanding of Spain's history as a product of many cultures and peoples which, from the arrival of the Iberians on the Peninsula to the unification of the disparate Christian and Moorish kingdoms under the crown of Castile in 1492, contributed to what would eventually become the Spanish nation and the Spanish empire. Early in the work, the writer confesses that, «I have always regarded Spain as my second home and I have wanted to know about its enduring quality, not its current preoccupations» (1968: 25). Having stated this, he embarks upon a literary tour-de-force that to the untrained eye might seem strange, but which is in fact a carefully-charted itinerary through the history and culture of Spain. The order of the work's chapters reveals Michener's sense of the development of Iberian history. It is a movement that flows from its ancient past to its Roman and Arab glories (Badajoz, Toledo, Córdoba); to Las Marismas, where the Arabs raised horses and experimented with the cultivation of rice; on to Seville, home to time-honored Christian and Muslim rituals; and then to Madrid, Salamanca and Pamplona, the heart of Christian Spain and birthplace of the Castilian language and the Spanish Empire. Next, he moves to Barcelona and Teruel, ancient cities that also saw some of the heaviest fighting of the Spanish Civil War, with an intervening reflection on "The Bulls», which are not only the enduring symbol of Spanish culture but also carry associations with Andalusia and some of the major conflicts of the Civil War. The book ends in the center of Catholic Spain, Santiago de Compostela, which famed Spanish literary scholar and historian Américo Castro believed to be 
pivotal to Spanish eternal self-fashioning (Michener 1968: 326-327; Castro 1975: 362-406). As we shall see, it was here, also in Santiago, where an important phase of Michener's spiritual journey came to a profoundly-moving conclusion.

Closer examination of the structure of the book is even more revealing than the simple consideration of the thirteen stated chapters of the work. Over the almost eight-hundred-page span of Iberia, Michener has subdivided his narrative into two-hundred-two unnumbered subsections of varying lengths that explore virtually every aspect of Spanish history, language, life, customs, geography, cuisine, politics, art, music, architecture, dance, nature, pastimes, religion, and current events. They also provide a wealth of observations by Spaniards themselves and a thoroughgoing chronicle of Michener's travels and activities as well as a penetrating analysis of his inner life. And as if the word were not sufficient to transport the mind to practically every cultural and historical artifact of Spain, the reader's eyes delight in the mysterious black-and-white plates of the famed international photographer Robert Vavra, who was not only an intimate friend of Michener but also an avid Hispanophile who moved to Spain from 1958 to 1964 just to study and photograph bulls. Few books provide such a comprehensive overview of Spain as this classic of travel writing, which fully engages -both textually and visually- with every aspect of Spanish life and history. Stephen J. May, in his biography of Michener, notes that the chief model for Iberia was H.V. Morton's conventional travel book A Stranger in Spain (1955) and that likewise the author inspired himself in other texts such as W. Somerset Maugham's Don Fernando (1935) or V.S. Pritchett's The Spanish Temper (1954). However, «[w] hereas Morton was lyrical and often nostalgic, Michener would be didactic and analytical, particularly when discussing the effects of Franco's regime on the country» (2005: 184).

Having first traveled to Spain in 1932 at the age of twenty-five, Michener came to his beloved Iberia as a "chart boy" on the "Clydeside», a Scottish vessel that shipped coal to Italy and then brought Spanish oranges back to Scotland to be used in the making of marmalade by the factories of Dundee (Michener 1968: 5). Spotting Finisterre through the mists of the pitching ship, the young Michener, ever the student of history, recalled that this westernmost promontory of the European continent had seen the marauding vessels of Sir Francis Drake, as well as the assembly of the Spanish Armada, prompting Michener to comment that «it challenged the mind» (1968: 5). Readers of Iberia find that, above all, this is a work that is replete with historical data about Spain, so much so that the author himself once joked in an interview that the book «tells you more about Spain than you want to know» (Day 1977: 127).

Scattered on practically every page are historical data that Michener skillfully intertwines with accounts of personal encounters. For example, his description of the iconic "Dama de Elche», a statue that is believed to have been sculpted by Iberians sometime before the birth of Christ, leads to a discussion of a certain gentleman, a "Spanish Charles Boyer», whom he frequently saw during his time in Madrid. Michener's penchant for meeting locals led to his befriending of this man, Manolo Torres, who, it turns out, was Madrid's legendary maker of flan (1968: 345-346). Michener then shares Torres's recipe for the perfect flan, which segues into a discus- 
sion of Don Manolo's love of opera and leads Michener to recall his first experience of seeing a zarzuela as a teenage deckhand (1968: 346-347). A skillful writer, at this almost mid-point of the book Michener thereby brings us back to the original pages of his work, to one of the first reasons that he offers for having fallen in love with "romantic» Spain. This, in turn, brings the reader back to the very first sentence in Iberia, Michener's clearly-stated reason for writing the book: «I have long believed that any man interested in either the mystic or the romantic aspects of life must sooner or later define his attitude concerning Spain" (1968: 5). But, as Michener will also show over the course of the work, and as he avers in the second sentence of Iberia, the subject of the book is unusual: «For just as this forbidding peninsula juts into the Atlantic and stands isolated, so philosophically the concept of Spain intrudes into the imagination, creating effects and raising questions unlike those evoked by other nations» (1968: 5). Michener's approach to answering these questions is a combination of fate and also his unique formula for tourism:

I cannot remember now how I discovered my technique for exploring a strange land, for I have followed this procedure for as long as I can recall. I enter the country unannounced and without a letter to anyone. I stand back and look at the scene before me, talk with anyone who cares to talk with me, then go to the bus station and buy a ticket for the end of any random line. This drops me in some little village out in the country, and there I spend a couple of days just sitting and looking and talking. This produces some very dull days, but also some memorable ones (1968: 11).

Such «memorable days», which can be found on almost every page of Iberia, are usually captured in the lively conversations with individuals of every social class, revealing not only the thoughts and feelings of the Spanish people but also providing us with many traces of the author's inner life.

In another instance of engaging travel writing, Michener enlivens his narrative by offering an account of how his plans fortuitously went awry. Indeed, in Michener's case, Spain was the site of extraordinary happenstances. The youthful writer's first days not only brought his first steps on Spanish soil, his befriending of a local workman, his first paseo ("courtship walk»), his first zarzuela, and his first bullfight; it also brought an exceptional encounter with Niceto Alcalá Zamora (1877-1949), the first Prime Minister and then President of the Second Spanish Republic, just before the outbreak of the Civil War. As Michener recounts the event, "It seemed that the only buses then available ran to Burriana [from which he had just come], but there was a railroad which wandered about the countryside, and on the advice of a straggler I purchased a ticket to Teruel, thus projecting myself into a corner of Spain not often visited by strangers» (1968: 11). From there, the young traveler went to Valencia, where he was to rejoin his ship. While passing through one of the main squares of the city, a long procession of men headed directly towards the youthful Michener. In the midst of the group was Alcalá Zamora, who briefly paused to greet the foreign visitor in what would seem to have been an unimportant meeting. When the President asked Michener where he had visited in Spain, the young man responded by saying, «Teruel». After a long silence, the president only 
made a simple observation: «Teruel. Not many get to Teruel» (1968: 22). Yet, this chance encounter that appeared to end in an empty comment by the President was not to be lost on Michener. As we shall see, Teruel was to have particular significance in the life of Spain and in Michener's personal life.

It is these personal encounters with individual Spaniards that make Iberia not only a travelogue that describes innumerable tourist destinations across Spain but also a collage of how Spaniards themselves have viewed their customs, cuisine, politics, religion, pastimes, language, psychology, and history. Illuminating these opinions are Michener's often lengthy historical and cultural explanations, which bring into focus the significance of issues that arose from seemingly chance interactions with locals. Thus, Michener enshrines the principle that unplanned encounters with local citizens often served as the medium for profound insights into the heart and soul of both the individual and the nation, as sociologist Dean MacCannell has noted: «Tourists know that for everything that is said or seen, there is the unsaid and the not seen. Everything attracting the gaze, every representation, generates its own 'beyond'» (2011: 205).

Yet, what precisely is the «beyond» of Spain for which Michener is searching? In something of an unflattering review published when Iberia first appeared in 1968, critic Robert Payne of the New York Times made the following evaluation of Michener as the writer: "What is surprising is that there are so few surprises. There are no adventures. Mr. Michener is the cautious traveler, interested in the local folklore, the music, old churches, the faces he sees outside the hotel window. The nerve ends are never exposed» (8). The sensitive reader, however, will find that throughout Iberia one gets a profound sense of the concerns and the struggles of Michener at many moments in his life, all of which have been associated with Spain. Although he affirms that he is primarily concerned with Spain's "enduring quality" and not with its "current preoccupations», Iberia demonstrates that Michener is, indeed, intensely interested in the current situation of the nation. Nonetheless, it is also clear that the author's overriding preoccupation is the search for what constitutes the eternal character of Spain. In an attempt to answer this one question, however, he enters into a series of nine «speculations» that surround the enigma of Spain's uniqueness. (1) Why was Spain emotionally confined to her peninsula whereas Italy was not? (2) Why did Spain never seem able to make up its mind as to where in the world its basic interests lay, and thus fritter away its colonial possessions? (3) After centuries of cultural, ethnic, and religious accommodation, why did Spain so suddenly extirpate from its soil Jews, Muslims, Protestants, Illuminati, and Jesuits? (4) With its drive toward uniformity and centralism, why has it so strongly preserved a regional pattern of life? Why has it repeatedly sought major solutions in dictatorial forms of government? (5) Why did Spain, when it was already one of the richest nations in Europe, spend so much energy gaining control of the New World and then allowing the influx of gold and silver to generate an inflation which converted it into the poorest country in Europe and one of the poorest in the world? (6) Prior to the Industrial Revolution, Spain was a leader in the manufacture of quality goods. Why, in an almost calculated fashion, did it hamstring its manufacturers, restrict its trade, and cripple its agriculture? (7) For several centuries Spain was one of the 
exciting leaders in art, music, drama, poetry, the novel, and philosophy, both as producer and consumer. Why did it abruptly abandon that leadership? (8) Why has Spain always seen itself as the defender and preserver of the Catholic Church, even considering it critical to save the Church from «Rome itself»? Finally, (9) What is the "central mystery» of Spanish psychology, that the Spaniard is at once outgoing, earthy, and vivacious as well as profoundly withdrawn and inwardly mystical? (1968: 23-25). But while Michener asks these questions about Spain, he is also conducting a deep-seated questioning of himself, a search that he must conduct among the "Other» because, as he states, «I have always regarded Spain as my second home» (1968: 23).

This seemingly polite comment in many ways reveals the reason for Iberia's greatness both as a work of travel writing and as a testimony to the spiritual inclinations of Michener the man. As he confesses in his autobiography, The World Is My Home: A Memoir (1992), which was published just five years before his death, Michener's origins have never truly been discovered. Never having known his father, the writer speaks of his mother, Mrs. Mabel Michener of Doylestown, Pennsylvania, acting as the caretaker of numerous orphans, keeping a roof over their heads by temporarily occupying rental properties as she prepared them for paying occupants (1992: 436-437). Never truly knowing one home and always feeling the sting of poverty, Michener and his mother moved constantly. Michener comments that his youth was one of hard work, constant study, intense athletic activities, and a rigorous reading regimen (1992: 447). Anxious to make his way in the world, the young Michener traveled as often and as far as he could, discovering, as we have seen, that Spain was truly a spiritual home filled with seemingly kindred spirits. Yet again in Teruel, he recalled the legend of Los amantes de Teruel (The Lovers of Teruel), a celebrated tale of tragic love that was popularized by numerous writers such as the Golden-Age master Tirso de Molina (i.e., Fray Gabriel Téllez) and the Romantic author Juan Eugenio Hartzenbusch. In the streets of the city, the traveler unites place, legend, time, history, and his own story: "What was important, I realized, was not the detail but the universal fact that young men leave their villages in search of adventure that will make them famous or success that will make them rich, the problem with the storyteller was to reflect the permanence of this theme» (1968: 692). As he so often does, Michener draws a connection between the adventures of travel in which we plumb the unknown, and in doing so, find what was always within us, thereby uniting ourselves with those of the past as well as with those of future generations.

As Michener explained of his very first encounter with the men who swam out to the Clydeside with barrels of oranges and who seemed to be exerting vast energies, these men should have been straining and struggling under the weight of their burden:

But the men thus engaged were so handsome, their smiles so compelling that there was something different about them, something powerful and stoic. This was their lot and they would not complain. Ashore some were having breakfast and they invited me to join. I knew that I was taking someone's share, but I could not resist such an opening meal in my new country and I paid my bargeman for my share 
of food. I can taste it yet: anchovies, which have always been my delight, hard bread, harder cheese and red wine. How good it was, how honest in its Spanish quality (1968: 9).

It was this experience that was to anchor Michener in "his» new country for the rest of his life: "It is this Spain that has been with me through the years, and whenever in subsequent visits I have again come close to that particular vision I have felt at home» (1968: 9). In Spain, the writer finds individuals who are what he has been. In his 1997 obituary of Michener, Albin Krebs succinctly notes the extent to which the author was extraordinary by observing that Michener had survived a "Dickensian» childhood, published his first novel at age forty, for which he won the Pulitzer Prize, and became «one of America's favorite storytellers with grand-scale novels» (8). A child of hardship, want, and hard work himself, Michener shares particular bonds with the Spaniards: industriousness, joy, youthful energy, vivaciousness, honesty, earthiness, optimism, and, above all, stoicism. It is these elements that make Spain a land of eternal greatness and a source of everlasting youth and renewal. Every visit to Spain was, in some way, a reconnection with the author's youth, and thus, a reinjection of energy and hope.

More than anything, Michener's love of Spain was based on what he perceived as the genuineness of the Spanish people. He once baldly remarked that "Spain, you know, is a unique area. It's always attracted fellows like me -people with an appreciation for the authentic statement. There's not much phoniness in Spain. It's a rugged, to-hell-with-you country -a first-rate country that makes little concession to the artist. I think that's why the artist had always liked it» (quoted in Day 1977: 131). This statement about the nature of Spain reveals much of how Michener views himself as he journeys along the path of life: «I do not think of myself as a romantic dreamer; my life has been too hard for that indulgence. But when I have suffered my physical setbacks I have muttered a saying I heard once but whose source I have not been able to identify: 'I will lay me down and bleed awhile, then rise and fight again'. I have been persistent» (1968: 499). As he points out in the section on Toledo, the writer despises what he perceives to be the shallowness and falsity of the booming tourist trade, which is the antithesis of Spanish honesty:

As I left the Zocodover, I was confronted, wherever I went, by rows of little shops selling acres of the cheapest tourist junk: damascened ash trays, inlaid penknives, letter openers that tried to make you believe they were ancient Moorish daggers, florid ceramics showing a wan knight tilting at a windmill, and gaudy banners woven with iridescent colors. These graceless shops numbered not in the dozens but in the hundreds, and it was depressing to think that the once-great crafts of Toledo, which had supplied the medieval world with splendid wares, had so degenerated (1968: 96).

Anything but eternal, the souvenirs of modern Spain leave the writer feeling empty, unlike any number of plazas, buildings, mountains, and backwaters that for $\mathrm{Mi}$ chener embody the essence of eternal Spain. 
Among the many measures of the eternal glory of Spain that are dear to Michener are genealogical tables of royal families, literature, art, music, and, especially, philosophy. Agreeing with Américo Castro's assertion that «the Spaniard has scarcely been interested in philosophy, except when it has been able to escape pure rationalism", the writer discusses at length the contributions of eminent Spanish philosophers across cultural backgrounds and across the ages, such as Quintilian, two Senecas, Maimonides, Averroës, Avicenna, and José Ortega y Gasset (Castro 1976: 31). Likewise, there is a seemingly endless series of Spanish writers who have graced the literary landscape with their masterpieces and who have inflamed the imaginations of other authors the world over: besides Hartzenbusch and Tirso de Molina, who have already been mentioned, there were Fray Luis de León, Emilia Pardo Bazán, Rosalía de Castro, the anonymous author of the Cantar de Mio Cid, Cervantes, Miguel de Unamuno, Santa Teresa de Jesús, Ana María Matute, San Juan de la Cruz, Pío Baroja, Federico García Lorca, and Lope de Vega, to name but a few. Then, there are the many musicians who have enriched Michener's listening pleasure with their works: Manuel de Falla, Isaac Albéniz, Enrique Granados, Pablo de Sarasate, and Tomás Luis de Victoria, and singers of flamenco like the celebrated "Gafas», who sang a petenera -a medieval flamenco ballad- about a "forbidden Jewess who brought disaster to her village and herself». Of this particular petenera Michener comments, "It is in a very real sense my particular song of Spain» (1968: 290). Finally, there is also the host of outstanding Spanish artists and architects who have forever changed the world's conception of beauty, such as Pablo Picasso, Antonio Gaudí, Francisco de Goya, Diego Rodríguez de Silva y Velázquez, Francisco Zurbarán, Joan Miró, and the Cretan who in almost every way became Spanish, El Greco. All of these luminaries figure prominently, as in Michener's apparent meanderings throughout Spain they come to life in the smallest of towns and the greatest of cities, an unbroken chain of civilization from the ancient past of the prehistoric caves of Altamira to the streets of modern Madrid.

Any contemplation of the eternal character of Spain must consider the enduring quality of the Spanish land. Yet again in search of an experience of the bulls, this time to see where the "Concha y Sierra" bulls -some of the finest- were raised, Michener travelled to Las Marismas, an area of coastal marshes along the southern estuary of the Guadalquivir River. One of the largest nature sanctuaries in Europe, part of which in 1969 was declared to be the Coto Doñana National Park, the area is one of the most important resting and breeding grounds for thousands of migrating birds. Michener explains that to appreciate the area, and the land of Spain in general, "we must watch it through one whole year», and, as is fitting, by observing the movement of the birds (1968: 217). Thus, the writer follows the paths of various fowl in each of the seasons, as the land undergoes, quite literally, the ebb and flow of the waters, the cold and the heat, and the ancient cycles of death and rebirth. It is along the edges of this wild wonderland that one finds the small town of Sanlúcar de Barrameda, which, while seemingly an outpost of no importance, actually played a critical role in the history of Spain.

Like so many apparently insignificant places in the nation, Sanlúcar was once a critical link between the Spanish homeland and its colonies throughout the 
world. Michener notes that Columbus left from this port on his third voyage to the New World, and, what is even more significant, that all Spanish galleons returning from the colonies were required to stop at this outpost. The younger sister of Queen Isabella II and her husband, a son of the King of France, were banished here for fear of their pretensions to the throne (1968: 232). Likewise, the humble town of Medellín had sent forth Hernán Cortés to become the conqueror of Mexico, the poor hamlet of Trujillo was the home of the family of Francisco Pizarro, the conqueror of Peru, and Jerez de los Caballeros had given birth to Vasco Núñez de Balboa, the first European to gaze upon the Pacific Ocean (1968: 67, 70, 80). For better or for worse, these conquistadors had also contributed to the legacy of eternal Spain, even in lands far beyond the shores of the Iberian Peninsula.

Much can be told of how the Spaniards think and feel about themselves from the Castilian language, and Michener, who frequently complains of his «poor Spanish", offers examples of colorful phrases that seem to have metaphysical transcendence. There are expressions such as duende ("spirit»), gracia ("good humor»), ambiente ("atmosphere»), pundonor ("sense of honor») and sinvergüenza ("one lacking a sense of honor»). He also comments on the adjectives estupendo, maravilloso, fantástico, and magnifico (which Michener believes are rarely used appropriately by non-native speakers of Spanish), and on the idiom Viva yo («I come first»). All of these words and expressions demonstrate for the travel writer the peculiarly Spanish outlook on life that is a combination of honor, pride, vivaciousness, and fierce independence (1968: 50-56).

A uniquely Spanish custom that is especially dear to Michener's heart is bullfighting, which the writer discusses countless times and from practically every perspective throughout the length of Iberia. Witnessing a bullfight in his very first days in Spain, Michener was once again connected not just with the present, but with the ghost of ancient Iberia. He notes: «When the bull killed the first horse -because if I remember correctly either pads were not used that day in Valencia or only inadequate ones if they were- I understood that I was participating in a tribal tragedy dating back to prehistoric times and not in a game» (1968: 18-19). In a telling caption below a shadowy black-and-white photograph of a picador confronting a bull, Michener underscores the enduring and truly Spanish quality of the bull: «Don Quixote [...] a wash drawing by Picasso [...] an echo from the Caves of Altamira [...] a bull and picador separated from their forms [...] all these can be seen at certain moments of the corrida» (1968: 635). The writer traces in minute detail every aspect of the "culture of the bulls» as he discusses every member of the bullfighting team and his responsibilities, the structure of the bullfight, the six «components» or maneuvers that each fighter is supposed to perform, the qualities of the most «noble» bull, the involvement of the fans, and the most famous bullfighters. He even comments on the lists of statistics, the places and the stars of important matches (1968: 625-675). Michener once again betrays his early assertion that he is not interested in Spain's «current preoccupations» by posing a very modern, political question:

On the other hand, the perceptive traveler soon discovers that bullfighting is an anachronistic spectacle; if the Republicans had won the Civil War in 1939 I sup- 
pose they would have outlawed it in deference to progress, and most progressive Spaniards would have approved. The victory of Generalísimo Franco provided the art with a reprieve, for bullfighting is essentially a reactionary operation upon large areas of uncultivated land and a feudal system; now that a new generation of managers is about to take over responsibility from Franco, men alert to opinion in Berlin and London, it is quite possible that bullfighting will come under serious pressure. It will be interesting to see if its 1967 return to television will become permanent (1968: 670-671).

This eternal sport of Spain, like so much of the nation's identity, seems to bring Michener back to the Civil War, a topic that haunts the writer's mind and spirit as much as it had haunted many other British and American travel writers before him.

In the penultimate chapter of Iberia, Michener engages in an extended meditation on Teruel, this time not as one of the first towns he was to visit in Spain, but rather as a provincial capital that had been the site of significant events in the recent history of Spain. The writer explains that Teruel had markedly changed since his first visit in 1932:

Those buildings to the left and those big apartments to the right. They weren't here when I knew the place. And the more I saw the more I realized that Teruel was not going to be the way it had been thirty-four years ago; the changes were to be of a magnitude that I would sometimes be unable to comprehend (1968: 684).

Although the now seasoned Hispanophile was returning on something of a sentimental journey, much more was going on than a simple, updated visit. While observing some buildings that he seemed to remember from his first visit in 1932, Michener makes a wry observation: "They looked as if they must have been there when I was first in Teruel, but some tremendous force had ripped them apart, say an artillery bombardment during the Civil War» (1968: 685). After making some historical dalliances, the writer suddenly finds himself thrown into a moment of personal confusion which is brought to life by a recollection of that terrible war in which, by highest estimates, over two million people died. Why, of all people, did he not join the celebrated Abraham Lincoln Brigade and fight in Spain? Michener accuses himself sharply:

I had watched at close hand the birth of the Republic and had seen its first faltering steps; I had spoken with the president and while he had not impressed me I had applauded many of the changes his party had introduced into Spanish life ... That change was overdue in Spain, I knew better than most, and when an army revolt arose to end that change I was desolate. Of all the young men available in America in those crucial years, I should have volunteered to defend the Republic, for I saw clearly what must ensue in Europe; I was convinced that a world war was upon us and that in the end my country would be involved (1968: 696).

The author continues to describe his anguish over the next several pages, offering the explanation that, as much as he had wanted to support the Republican government, it had become clear in the latter months of 1938 that «[t]he defense of a free 
democracy had been subordinated to the expanded goal of establishing a Communist government», which he simply could not support (1968: 697). Speaking of his voluntary service during World War II, despite his Quaker heritage, Michener avers that it was not cowardice that kept him away from the struggle.

Teruel eventually fell to the Nationalist forces of Francisco Franco, and yet, even in 1968, sadness still filled Michener's heart. He writes, "With the death of this mountain city I experienced a spiritual agony that has not diminished through the years" (1968: 700). Still, the lesson to be learned from Teruel is also very much a part of the eternal quest for renewal. From death, there is always new life; from defeats come victories. A local guide in Teruel offers Michener something of the secret of eternal Spain: «We saw the other day that the symbol of Teruel is a bull. But what particular bull? A Saracen bull sent against the Christians as an enemy. It came to destroy us, but we converted it», affirms the man. He then adds: «If the Spaniards in 1171 were able to accept such a bull as the symbol of their city, then other Spaniards in 1939 should have been able to accept their recent enemies" (1968: 709-710). Michener concludes that this is, indeed, what has happened. As the writer was about to reveal, he himself, like Spain, was to rebound from a great assault.

The writing of Iberia was much more than a typical long, investigative stay, as so many of the other trips in Michener's life had been. In the first pages of the book the author explains, "During the four decades that I have traveled in Spain I have always wanted to describe the impact this vibrant land has had upon me, and now I have the opportunity to do so" (1968: 5). Yet, what was that particular opportunity which, after four decades, finally afforded Michener the chance to reflect on his «second home»? On a September afternoon in 1965, the writer was afflicted with «a violent case of what [he] thought was indigestion» (Michener 1992: 417). In the early hours of the next morning a physician was summoned, who, upon checking the writer's pulse, called for an ambulance immediately: Michener had suffered a heart attack. After months of recovery and not being able to focus on the writing of his book on Russia, the author made a fateful decision to return to Spain, "the splendid country whose history and mores I had come to know so well» (1992: 420). The plan of physical, and, especially spiritual, renewal was very clear:

As a young man, as I have said, I had traveled for a while with a group of bullfighters -one of whom was Domingo Ortega, who later became famous-and now I wanted to see Spain again, to run with the bulls at Pamplona and to make the traditional journey to Santiago de Compostela, the ancient holy site in the northwest corner of the country. I felt that if I could do those things comfortably, I could work my way back into a writing career. My return to Spain was a spiritual and physical pilgrimage of the utmost importance (1992: 420).

In particular, Michener explains the significance of Teruel in this return journey, the first place he was to visit and the testing site of his physical and mental abilities. Yet, even though it was ostensibly just a proving ground, Teruel held much more meaning for the author: 
Teruel, where I had first seen the true Spain more than three decades ago [...] Teruel, where I had lived and died with the Spanish Republic [...] Teruel, which had been a magnet for years, now became important in another way, and when I discovered that I could negotiate those hilly streets I decided that I was ready for the feria at Pamplona and the long trip across northern Spain (1968: 794).

Uniting himself with Spaniards from the distant past, Michener did indeed run with the bulls, witnessing the goring of another man several feet away from him and narrowly avoiding the same fate as the bull's horn came within six inches of his chest (1992: 421). This brush with death, just like his heart attack, was for Michener a source of renewal that almost seemed to fit into a divine plan, which the writer appears to recognize, and which he confirms by the next stage of his journey: following the pilgrims' route to Santiago de Compostela.

Michener records that his pilgrimage was a crucial phase in his personal and professional life. As he made his way along the route, the writer recalled two previous pilgrimages he had made to Santiago, and on this momentous trip, he fortuitously met many old friends who had helped him to understand the intricacies of the local history. Ever the cultural tourist, Michener shares his delight with, and the recipe for, caldo gallego, an ancient staple of Galicia and a reminder of the heartiness of the local peasants. Finding crucifixes everywhere along the road to Santiago, he underscores the significance of the Catholic faith to the Spanish people. A caption next to a beautiful plate of a carved wooden crucifix states that " $[\mathrm{t}] \mathrm{o}$ the Spaniard a crucifix is a reminder of the central emotional event of his life», reasserting the fact that the Roman Catholic faith has been an essential element of the history of Spain. Raised as a Quaker, Michener claimed not to find his intellectual and emotional guidance in the Bible, but in the great English poems he had learned as a youth (1992: 4). Yet, despite his apparent indifference to the religious condition, the writer outwardly confesses his deepest conviction: «Throughout this chapter I have spoken of being on pilgrimage, and now, as I return from Finisterre to Compostela, I think it is not inappropriate to speak of this pilgrimage, which was a most real thing» (1992: 793).

Although he first explains that he spent a week in Santiago de Compostela to study the sculptures of the medieval cathedral, Michener was about to fulfill the true purpose of his pilgrimage, which was reaching its climax on the feast day of St. James (July 25). As the full pomp of the Catholic Mass was unfolding in Compostela's renowned cathedral, with the massive censer swinging across the nave, the clergy all arrayed in their finery, and the organ blasting, Michener was up on the high altar, in the passageway behind the gilded bust of Saint James:

It was a dazzling moment, as rich in pageantry and as filled with the spirit of Spain as any that I had witnessed, and there I hid in the darkness as if an interloper with no proper role in the ceremonial except that I had completed my vow of pilgrimage and stood at last with my arm about the stone-cold shoulder of Santiago, my patron saint and Spain's (1968: 795).

This was perhaps the pinnacle of Michener's life, for although he never declared himself a Roman Catholic, this communion with the patron saint of Spain was to 
mark the beginning of a new life for the author. This interlude in Santiago, he attests, was to mark a moment of mental and spiritual rebirth, as well as a rekindling of his professional energies. As he confesses, «in a surge of reassurance [I] started to write the book of mine that will probably live the longest, Iberia, a testament to a land I love and to my own regeneration» (1992: 421).

As if to reaffirm the centrality of this final pilgrimage to Santiago and the writing of the book, Michener yet again links his personal history with the history of eternal Spain, implicitly adding his book as the latest in a long line of timeless books that have sought to capture some aspect of the essence of Spain:

Iberia is my letter of gratitude to my notable forebears: George Borrow, who wrote The Bible in Spain, one of the noblest of all travel books; Prosper Mérimée, who after the briefest of visits wrote his novella Carmen, and Georges Bizet, who set the tale to imperishable music; and Miguel Unamuno, the philosopher who wrote of Spain's attitude toward the world (1992: 421).

Just as Michener discovered Spain in his youth and was so inspired by it that the nation was never to leave his thoughts or his heart, so Iberia is the embodiment of the author's love of that land and his devotion to the Spanish people.

For all the praise it received, not all critics embraced Iberia with the same sense of inspiration as its author. Sir Raymond Carr, one of the foremost Hispanists of the twentieth century, wrote less than enthusiastically about Michener's work in a review amusingly titled «Allá va! Ra! Ra! Ra!». In Carr’s opinion,

[Michener's] long, diffuse book contains fascinating historical illustration; but it is the Moors, Ferdinand and Isabella, the Jews, St. James, not Prim, Cánovas, and Azaña, who fascinate him. Of course he has the middle-aged intellectual's guilt about the Civil War, but he has no feeling for the drearier stretches of modern history, where things are gray rather than black and white, even in Spain, and which explain so much at the cost of so much boring work.

Michener's work has often been criticized for not engaging enough with the current political situation of Spain as he found it in the years leading up to the publication of Iberia in 1968. Although he frequently questions what the future of the nation will be after the departure of Generalísimo Francisco Franco from governance, Michener does not engage in extended discussion about the achievements or failures of the regime. Nor is the writer a professional Hispanist, trained formally in the Spanish language or any aspect of Hispanic Studies. What Michener does do is to amass a treasure trove of data about Spain, much of it through his own reading and experiences, complementing it with the research of a team of assistants. As the author himself states in Iberia's "Acknowledgements", he has painstakingly verified the facts of the book against the work of noted professional Hispanists such as Reginald Trevor Davies, Henry Kamen, Cecil D. Eby, Theo Aronson, Henry V. Morton, Walter Starkie, and others, and complemented it with literally thousands of personal discussions. 
Yet, this somewhat intimate engagement with the life of «real» Spaniards and this personal approach to the writing of Iberia led to other unfavorable critical assessments, such as that of the Kirkus Reviews on April 1, 1968: "There are times, though, when Michener's reportage is just too intrusive and cloying. And once again he is bland, and his opinions are ordinary. But he does give good information about Spain» (2011). In spite of such assessment, Michener never allowed his many harsh critics to discourage him from writing. In the final chapter of his memoir he discusses them compassionately, adopting the attitude of his true concern in life -making worthy contributions that are lasting, just as he sought to discover the essence of eternal Spain: «Writers should write what they feel has to be written and trust that with the passing years those who did not like the book originally will see that sub specie aeternitatis it was a truthful effort. Writers can afford to wait» (1992: 509). Although Michener was not a professional Hispanist, he did make a true and eternal contribution to Hispanism, which was to inspire future generations of professors, scholars, and travelers -like myself- to engage in deeper investigation into the complexity of such a plural nation as Spain.

In the opening pages of his autobiography, which Michener wrote at the age of eighty-five, he recounts an incident that occurred eighty years previously. A «tired old tree» produced a bumper crop of apples the likes of which the young Michener had never seen. When he asked the farmer how this was possible, the man explained that hammering rusty old nails into the tree had given it a shock «to remind it that its job is to produce apples». Was it the minerals in the rust that had done the trick or the number of nails employed? The wise farmer commented that "[i]f you're goin' to send a message, be sure it's heard», also noting that a «substantial jolt lasts about ten years" (1992: 4). Looking back on his career, especially the years 1986 to 1991, when he wrote eleven books, publishing seven of them, Michener queries whether it was the fear of death that had shocked him into mass production, just as it did John Keats, but the author concludes otherwise:

I think not. I write at eighty-five for the same reasons that impelled me to write at forty-five: I was born with a passionate desire to communicate, to organize experience, to tell tales that dramatize the adventures which readers might have had. I have been that ancient man who sat by the campfire at night and regaled the hunters with imaginative recitations about their prowess. The job of an apple tree is to bear apples. The job of a storyteller is to tell stories, and I have concentrated on that obligation (1992: 6).

If we look carefully at his life's achievements, we find that, truth be told, it was not a fear of death that propelled Michener forward on his appointment with destiny; rather, it was the fulfilling of his lifelong desire to tell the story of his cherished Spain that was most likely the cause for the ailing patient's recovery, rejuvenation, inspiration, and spiritual realization. In point of fact, it was the writing of Iberia that was to supply the author with the necessary energy and spiritual consolation to fulfill his ultimate destiny as the world's storyteller.

Spain has changed enormously since Iberia's publication in 1968; however, the eternal search for «Spanishness» remains the same. Michener found Spain to 
be the land of his own lifelong quest for self-knowledge and personal fulfillment. And, just as Cervantes's beloved masterpiece Don Quijote holds different truths for different stages in one's life, Iberia not only tells the tale of the seasons of Michener's life, it offers generations of readers a timeless conduit to the eternal truths and wonders that Spain and its culture embody.

Recibido: junio de 2018; ACEPTADO: octubre de 2018. 


\section{BIBLIOGRAPHY}

Becker, George J. (1983): James A. Michener, New York: Frederick Ungar.

CArr, Raymond (1968): «Allá va! Ra! Ra! Ra!», The New York Review of Books, December 19: 29-30.

Castro, Américo (1975): La realidad histórica de España, México, D.F.: Editorial Porrúa.

Castro, Américo (1976): «The Meaning of Spanish Civilization», in José Rubia Barcia and Selma Margaretten (eds.), Américo Castro and the Meaning of Spanish Civilization, Berkeley and Los Angeles: University of California Press. 23-40.

Cavestany, Juan (1997): «Muere el cronista norteamericano James Michener», El País, October 17: 44.

DAY, Arthur Grove (1977): James A. Michener, Boston: Twayne.

ECONOMIST, THE (1997): «James Michener», 30 October: 92.

Fuertes Manjón, Roberto (2016): «España como descubrimiento en la obra de James Michener», Argutorio: Revista de la Asociación Cultural "Monte Irago" 36 (Semestre II): 38-42.

KIRKUS REVIEWS (2011) [1968]: «Iberia: Spanish Travels and Reflections», September 30. URL: https:// www.kirkusreviews.com/book-reviews/james-a-michener/iberia/; 10/06/2018

Krebs, Albin (1997): "James Michener, Author of Novels that Sweep Through the History of Places, Is Dead", The New York Times, October 17: 8.

Maccannell, Dean (2011): The Ethics of Sightseeing, Berkeley: University of California Press.

Martín, Ana (1997): «Veteranos del best-seller», La Vanguardia, October 16: 51.

MaY, Stephen J. (2005): Michener: A Writer's Journey, Norman: University of Oklahoma Press.

Michener, James A. (1968): Iberia: Spanish Travels and Reflections, New York: Random House.

Michener, James A. (1992): The World Is My Home: A Memoir, New York: Random House.

Michener, James A. (2015) [1968]: Iberia: Spanish Travels and Reflections, New York: The Dial Press.

Payne, Robert (1968): «One Man's Spain», The New York Times, May 12: 8.

Theroux, Paul (1992): The Happy Isles of Oceania: Paddling the Pacific, Boston and New York: Mariner Books/Houghton Mifflin. 